\title{
ПОВНОВАЖЕННЯ ЗАХИСНИКА ПРИ НАДАННІ ПРАВНИЧОЇ ДОПОМОГИ ІНШИМ УЧАСНИКАМ КРИМННАЛЬНОГО ПРОВАДЖЕННЯ
}

\author{
МАРТОВИЦЬКА Олена Василівна - кандидат юридичних наук, доцент \\ кафедри кримінального процесу та організації досудового слідства Харківського \\ національного університету внутрішніх справ \\ ORCID: 0000-0002-4483-861X \\ УДК 343.122 (477) \\ DOI 10.32782/EP.2020.3.15
}

\begin{abstract}
В статье выполнено теоретическое исследование законодательных, научных и прикладнъих вопросов относительно привлечения защитника в уголовном производстве для защить прав других участников уголовного производства. При этом проанализировано различнъе научнъе школь и позиции отдельньих ученых относительно исследованного направления и материаль правоприменительной практики, по которым высказанъ научные взгляды автора. Внесенъ конкретнъие предложения по усовершенствованию отдельных положений уголовного процессуального законодательства Украинъ и правоприменительной деятельности по изученным вопросам.

Ключевъие слова: досудебное расследование, уголовный процесс, право на защиту, зашитник, другие участники уголовного производства, правовая помощь, статус, положение, закон, прочессуальнъие правоотношения, участник, бункиия, научная позичия, следователь, дознаватель, прокурор, следственный судья, права и свободьл.
\end{abstract}

Постановка проблеми

Прийняття та введення в дію КПК України у 2012 році відкриває концептуально нову епоху розвитку кримінальної процесуальної науки, а також практики іiі застосування. Насамперед, на нашу думку, теоретичне переосмислення новел чинного КПК України та практичні напрацювання необхідні для ефективного забезпечення і реалізації прав, свобод і законних інтересів усіх учасників кримінального провадження.
При цьому, важливе значення має й реалізація правничої допомоги, яка на сьогодні отримала значно нові положення, що потребують свого подальшого переосмислення, теоретичного дослідження, втілення в практичну площину з метою удосконалення Кримінального процесуального законодавства. Чинний КПК України, зокрема у параграфі 5 «нші учасники кримінального провадження» глави 3 «Суд, сторони та інші учасники кримінального провадження»? містить вичерпний перелік таких учасників, до яких відносяться: заявник, цивільний позивач, цивільний відповідач, свідок, перекладач, експерт, спеціаліст, секретар судового засідання, судовий розпорядник. Враховуючи те, що в статтю 59 Конституції України внесено зміни, а також те, що питання надання правничої допомоги вказаним учасникам кримінального провадження на дисертаційному рівні не вивчалось, доцільно провести концептуальне дослідження 3 цього напряму.

Аналіз останніх досліджень і публікацій

Науково-теоретичне підгрунтя з цього напряму складається 3 дослідження наступних праць ечених, зокрема: C.С. Абламського, В.П. Бож'єва, В.В. Борисова, Т.В. Варфоломеєвої, Б.А. Ващука, В.І. Галагана, I.M. Гальперіна, А.А. Гарбовського, А.В. Головка, В.Г. Гончаренка, Ю.М. Грошевого, M.I. Гошовського, Є.В. Діденка, В.О. Дубрівного, М.В. Духовського, Я.П. Зейкана, 
О.А. Калганова, О.В. Капліної, Г.К. Кожевнікова, А.Ф. Коні, В.В. Аисенка, А.Д. Кокорева, Н.І. Клименка, О.П. Кучинської, О.О. Кочури, В.З. Аукашевича, Є.Д. Аук'янчикова, M.М. Михеєнка, Т.В. Омельченка, B.T. Нора, О.В. Панчука, Т.I. Присяжнюка, В.М. Савицького, М.В. Сенаторова, М.С. Строговича, В.М. Тертишника, А.Д. Удалової, І.Я. Фойницького, Т.Г. Фоміної, П.В. Цимбала, В.П. Шибіки, О.Г. Шило, М.Є. Шумили, В.Є. Юрченка, О.О. Юхна, М.О. Юхна, Ю.П. Яновича та інших.

Після набрання чинності КПК України у 2012 році питання участі окремих учасників кримінального провадження на рівні монографічних праць розглядались А.А. Аухундовим («Захист прав підозрюваного у кримінальному провадженні» у 2013 році), М.Г. Моторингіною («Сторона захисту у судовому провадженні у першій інстанції» у 2015 році), О.В. Маслюком («Процесуальна діяльність захисника зі спростування підозри (обвинувачення)» у 2017 році), I.В. Дубівки («Діяльність адвоката в стадії досудового розслідування» у 2017 році) та іншими науковцями. Незважаючи на значний обсяг зазначених та інших досліджень 3 проблем захисту учасників кримінального провадження, більшість питань залишається не вирішеними та $є$ предметом гострих наукових дискусій. Концептуально не проводились дослідження щодо захисту прав інших учасників кримінального провадження, зокрема цивільного позивача, цивільного відповідача, перекладача, а стосовно потерпілого, свідка дослідження проводилися фрагментарно, не враховуючи понад 590 змін і доповнень до чинного КПК України станом на кінець 2020 року.

\section{Формування цілей}

Удосконалення надання захисником правничої допомоги на стадії досудового розслідування є актуальним питанням сьогодення для України, враховуючи постійний моніторинг міжнародних інституцій 3 цих питань та враховуючи щорічне збільшення кількості звернень українців до Европейського суду з прав людини (далі - ЄСП $\Lambda$ ). Новели Кримінального процесуального кодексу, прийнятого у 2012 році, зокрема в частині надання захисником правничої допомоги іншим учасникам кримінального провадження на етапі досудового розслідування, внесло концептуальні зміни в цьому напрямі. У той же час, підписання Україною ряду міжнародно-правових актів та догово-

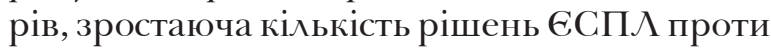
України, вимагає подальшого удосконалення теоретичних і правозастосовних питань надання правничої допомоги захисником, зокрема іншим учасникам кримінального провадження. Рішення Свропейського суду 3 прав людини, які стали частиною національного законодавства України, повинні враховуватись при дослідженнях, а також посадовими особами і захисниками при правозастосуванні, оскільки в цих рішеннях мова йде про виявлення цією судовою інституцією збільшення кількості порушень прав, зокрема й інших учасників кримінального провадження, що провадяться національними слідчими і судовими інстанціями. Забезпечення прав, свобод і законних інтересів особи є одним із головних чинників визначення демократичної правової держави, що гарантовані Конституцією нашої країни, а згідно зі ст. ст. 55 та 59 така професійна правнича допомога (була професійна правова допомога) повинна бути забезпечена всім особам, які потрапили у кримінально процесуальні правовідносини [1]. Існує нагальна потреба сьогодення щодо удосконалення захисту прав інших осіб, що беруть участь у кримінальному провадженні, оскільки чинне кримінальне процесуальне законодавство з боку науковців і практиків має зауваження теоретичного і прикладного характеру та виявляє проблемні питання при правозастосуванні, наявну наукову дискусію з піднятих питань, у зв'язку з чим 6 необхідність щодо теоретичного дослідження і напрацювання відповідних пропозицій і рекомендацій з метою удосконалення чинного національного кримінального процесуального законодавства 3 цього напряму.

\section{Виклад основного матеріалу}

При дослідженні доцільно розглянути питання відносно захисту прав, свобод і законних інтересів інших учасників кримінального провадження, зокрема: заявника, 


\section{Кримінальне право, кримінальний процес та криміналістика}

цивільного позивача, цивільного відповідача, свідка, перекладача, експерта, спеціаліста, секретаря судового засідання, судового розпорядника.

Заявник як суб'єкт кримінального провадження є новелою чинного КПК України, тому що у попередньому КПК України 1960 року не було передбачено такого суб'єкта кримінального провадження. Ним є особа, яка є дієздатною особою, досягла 16 років, тобто віку, з якого настає кримінальна відповідальність згідно зі ст. 383 КК України за завідомо неправдиве повідомлення про вчинення злочину, i не є потерпілим. Різниця між потерпілим і заявником згідно 3 положеннями статей 55 та 60 КПК України полягає в тому, що потерпілим є особа, яка подала заяву про вчинення щодо неї кримінального правопорушення, або заяву про залучення до провадження як потерпілого. Заявник - це особа, яка звернулася із заявою або повідомленням про кримінальне правопорушення, але це кримінальне правопорушення скоєне не стосовно неї, а іншої особи. Основним критерієм розмежування заявника від потерпілого є фактор заподіяння моральної, фізичної або майнової шкоди. Така шкода заподіюється виключно потерпілій стороні [2]. Питання участі заявника у кримінальному провадженні врегульовано законодавцем лише в одній ст. 60 «Заявник» КПК України. На нашу думку, таке відношення до цього учасника не відповідає сучасним реаліям, а отже, й не забезпечує відповідного належного та ефективного захисту його прав, свобод і законних інтересів потребує свого удосконалення. Цивільного позивача у кримінальному провадженні слід класифікувати на дві категорії, а саме: фізичну особу, якій кримінальним правопорушенням або іншим суспільно небезпечним діянням завдано майнової та/або моральної шкоди, а також юридичну особу, якій кримінальним правопорушенням або іншим суспільно небезпечним діянням завдано майнової шкоди. Обов'язковою умовою визнання особи цивільним позивачем є пред'явлення нею в кримінальному провадженні цивільного позову, оскільки інших процесуальних документів, таких як винесення постанови слідчим чи прокурором або ухвали суду про визнання особи цивільним позивачем, закон не встановлює. 3 моменту подання позовної заяви органу досудового розслідування або суду особа стає учасником процесу та набуває прав, передбачених положеннями ст. 61 КПК України. Особливості та сам порядок пред'явлення позову у кримінальному провадженні регулюються ст. 128 КПК України. Цей учасник має права та обов'язки, відповідно до ст. 55 КПК України як для потерпілого, у частині, що стосуються цивільного позову, незалежно від того, чи є ця особа фізичною чи юридичною особою. Орган досудового розслідування зобов'язаний надати цивільному позивачу інформацію про прийняті процесуальні рішення у кримінальному провадженні, що стосуються цивільного позову, долучивши до інформації їх копії. Випадки та порядок інформування передбачені у статтях 56, 111 , 112 КПК України [3, с. 204-205].

У кримінальному процесі майнову та моральну відповідальність за цивільним позовом несе особа, яка вчинила кримінальне правопорушення. У той же час, у багатьох випадках ця відповідальність покладається не на підозрюваного, обвинуваченого, а на інших осіб - цивільних відповідачів. Як цивільні відповідачі можуть бути притягнуті батьки, опікуни, піклувальники та інші особи, а також підприємства, установи та організації всіх форм власності, які в силу закону несуть матеріальну та моральну відповідальність за шкоду, завдану діями винних. Неповнолітня особа (у віці від чотирнадцяти до вісімнадцяти років) відповідає за завдану нею шкоду самостійно на загальних підставах. У разі відсутності у неповнолітньої особи майна, достатнього для відшкодування завданої нею шкоди, ця шкода відшкодовується в частці, якої не вистачає, або в повному обсязі їі батьками (усиновлювачами), або піклувальником, якщо вони не доведуть, що шкода була завдана не з їхньої вини. Якщо неповнолітня особа перебувала у закладі, який за законом здійснює щодо неї функції піклувальника, цей заклад зобов' язаний відшкодувати шкоду в частці, якої не вистачає, або в повному обсязі, якщо він не доведе, що шкоду було завдано не з його вини. 3 урахуванням матеріального становища потерпі- 
лого та особи, яка завдала шкоду, суд може постановити рішення про відшкодування нею цієї шкоди частково або в повному обсязі. Якщо фізична особа, яка завдала шкоду, сама довела себе до стану, у якому вона не усвідомлювала значення своїх дій та (або) не могла керувати ними в результаті вживання нею спиртних напоїв, наркотичних засобів, токсичних речовин тощо, шкода, завдана нею, відшкодовується на загальних підставах. Якщо шкода була завдана особою, яка не усвідомлювала значення своїх дій та (або) не могла керувати ними у зв'язку 3 психічним розладом або недоумством, суд може постановити рішення про відшкодування цієї шкоди ії чоловіком (дружиною), батьками, повнолітніми дітьми, якщо вони проживали разом із цією особою, знали про iï психічний розлад або недоумство, але не вжили заходів щодо запобігання шкоді. Права та обов'язки цивільного відповідача виникають з моменту подання позовної заяви органу досудового розслідування або суду, при цьому закон не вимагає, щоб особа, яка провадить розслідування кримінального провадження, виносила постанову, а суддя, суд - ухвалу. Із цього моменту виникають права та обов'язки цивільного відповідача, передбачені ст. 62 КПК України. Чинний КПК передбачає дві категорії представників цивільного позивача у кримінальному провадженні: а) представника цивільного позивача; б) законного представника цивільного позивача. Представниками цивільного позивача і цивільного відповідача у кримінальному провадженні можуть бути тільки захисники, тобто відповідно до ст. 45 КПК України - адвокат, відомості про якого внесені до Єдиного реєстру адвокатів України, якщо цивільним позивачем, цивільним відповідачем у кримінальному провадженні є фізична особа, та у випадку, якщо цивільним позивачем, цивільним відповідачем є юридична особа - іiі керівник чи інша особа, уповноважена законом або установчими документами, працівник юридичної особи за довіреністю [3, с. 205].

Щодо можливого захисту прав свідка, то відповідно до ч. 1 ст. 65 КПК України, свідком є фізична особа, якій відомі або можуть бути відомі обставини, що підлягають дока- зуванню під час кримінального провадження, і яка викликана для давання показань. 3 аналізу цього визначення, на нашу думку, не дуже вдалою є вказівка на виклик. У зв'язку 3 цим виникає логічне питання: чи буде особа свідком, якщо вона сама прийшла надати показання слідчому, дізнавачу, прокурору, слідчому судді. Ці положення, на нашу думку, потребує уточнення та внесення до вказаної статті відповідних змін.

3 цих питань доречно зазначав М.К. Треушников, що свідок є особою, яка юридично не зацікавлена у вирішенні справи [4, с. 198]. У зв'язку з цим, на думку В.Г. Пожар, не має юридичної зацікавленості в вирішені справи і представник свідка, що не виключає наявності у останнього процесуального інтересу [5, с. 1], що ми підтримуємо. Проблема правової регламентації права на захист свідків та інших учасників кримінального процесу довгий час залишалася поза увагою законодавця. Згідно 3 п. 2 ч. 1 ст. 66 КПК України свідок має лише право користуватися правовою допомогою адвоката при наданні показань та участі у проведенні інших процесуальних дій. Таке визначення правової допомоги значно звужує можливості свідка щодо отримання такої допомоги. 3 цього приводу необхідно звернути увагу на рішення Конституційного Суду України у справі за конституційним зверненням громадянина Голованя Ігоря Володимировича щодо офіційного тлумачення положень ст. 59 Конституції України (справа про право на правову допомогу) № 23-рп/2009 від 30.09 .2009 р.,у якому зазначено, що положення ч. 1 ст. 59 Конституції України «кожен має право на правову допомогу» треба розуміти як гарантовану державою можливість будь-якій особі вільно, без неправомірних обмежень, отримувати допомогу з юридичних питань в обсязі і формах, як вона того потребує (наведено зі скороченням) [6]. Чинний КПК України містить лише одну норму, присвячену наданню правової допомоги свідку. Перш за все, слід зауважити, що адвокат, який надає правову допомогу свідкові, не є захисником за своїм процесуальним статусом. Повноваження представника свідка - адвоката підтверджуються, відповідно до положень статті 50 КПК України, шляхом 


\section{Кримінальне право, кримінальний процес та криміналістика}

надання наступних документів: 1) свідоцтва про право на зайняття адвокатською діяльністю; 2) ордеру, договором із захисником або дорученням органу (установи), уповноваженого законом на надання безоплатної правової допомоги. Слід зауважити, що КПК України не визначає статусу адвоката, що надає правову допомогу свідку і не містить вказівок щодо його прав та обов'язків. Важливим $є$ й положення, що такий адвокат, на відміну від захисника, не користується процесуальними правами свідка. Таким чином, права вказаного адвоката при наданні правової допомоги свідку визначаються професійними правами та обов'язками адвоката, визначеними ст.ст. 20, 21 Закону України «Про адвокатуру та адвокатську діяльність» 3 урахуванням процесуального статусу свідка у кримінальному провадженні. 3 цих питань ми підтримуємо позицію О.В. Панчук, яка доречно запропонувала КПК доповнити нормою, яка б визначала, що адвокат свідка має право: 1) знати, у якому кримінальному провадженні викликаний свідок; 2) бути присутнім протягом усього часу провадження допиту чи іншої процесуальної дії за участю свідка; 3) заявляти відвід перекладачу; 4) роз'яснювати свідку його права та звертати увагу слідчого на порушення закону; 5) у присутності слідчого надавати короткі консультації свідку; 6) ставити з дозволу слідчого запитання свідку; 7) заперечувати проти незаконних дій слідчого та вимагати внесення заперечень у протокол; 8) ознайомлюватися з протоколами процесуальних дій, які проведені за участю свідка; 9) оскаржувати дії слідчого прокурору [7, с. 34]. Доцільно звернути увагу на те, що чинний КПК України не передбачає право свідка мати свого представника. Проте, представництво свідка у кримінальному судочинстві визнано на міжнародному рівні, зокрема у Конвенції про правову допомогу і правові відносини у цивільних, сімейних і кримінальних справах та у Европейській конвенції про взаємну допомогу у кримінальних справах. Обидва міжнародні документи ратифіковані Україною.

Отже, право мати представника у свідка у кримінальному процесі, хоча i не передбачено нормами КПК, фактично існує i $\varepsilon$ конституційним правом кожної особи, що передбачено ст. 59 Конституцією України. Тому представник свідка є самостійним суб'єктом кримінального провадження, який вступає в процес і діє виключно 3 метою захисту прав та законних інтересів особи, яку він представляє. Такий представник захищає процесуальний інтерес свідка (оскільки матеріального інтересу у свідка немає) який полягає у тому, щоб свідок найбільш повно реалізував належні йому права у кримінальному провадженні.

Відповідно до ст. 92 КПК Республіки Молдова адвокат свідка має право: 1) знати, по якій кримінальній справі викликаний свідок; 2) бути присутнім протягом усього часу провадження слідчої дії за участю свідка; 3) заявляти відвід перекладачу; 4) подавати заяви; 5) роз'яснювати свідку його права та звертати увагу особи, яка провадить слідчу дію, на порушення ним закону; 6) з дозволу органу кримінального переслідування звертатися до свідка з питаннями, зауваженнями та настановами; 7) заперечувати проти дій органу кримінального переслідування та вимагати внесення своїх заперечень у відповідний протокол; 8) ознайомлюватися 3 протоколами слідчих дій, які проведені за участю свідка, та вимагати внесення до них доповнень і зауважень [8]. Слід також звернути увагу на ст. 87 КПК Республіки Вірменія, де передбачено: «участие законного представителя свидетеля в следственных и других процессуальных действиях»: 1. Законный представитель свидетеля, не достигший возраста 14 лет, а с разрешения органа, осуществляющего уголовное производство, - также законный представитель несовершеннолетнего свидетеля старшего возраста вправе знать о вызове представляемого лица в орган, осуществляющий уголовное производство, и участвовать в следственном или другом процессуальном действии, сопровождая его. 2. Законный представитель свидетеля, участвуя в следственном или другом процессуальном действии, имеет право: 1) возбуждать ходатайства; 2) возражать против действий органов, осуществляющих производство по уголовному делу, и требовать внесения его возражений в протокол следственного или друго- 
го процессуального действия; 3) возражать против действий председательствующего в заседании суда; 4) знакомиться с протоколами следственных и других процессуальных действий, в которых он участвовал в ходе досудебного производства и подавать замечания в связи с правильностью и полнотой записей в протоколе; в случае участия в следственном и другом процессуальном действии, присутствия в заседании суда требовать внесения в протокол указанного действия или заседания суда записей об обстоятельствах, которые, по его мнению, должны быть отмечены. 3. Законный представитель свидетеля, участвуя в следственном или другом процессуальном действии, обязан: 1) подчиняться законным распоряжениям прокурора, следователя, органа дознания, председательствующего в судебном заседании; 2) соблюдать порядок во время заседания суда» [9]. Також слід відзначити, що в ч. 3 ст. 78 КПК Республіки Казахстан зазначено: «Свидетель имеет право давать показания в присутствии своего адвоката» [10]. Виходячи з наведеного, можна зробити висновок, що представник свідка повинен володіти наступними правами: користуватися допомогою перекладача або заявляти клопотання про надання його свідкові; заявляти відвід перекладачу; знати, у зв'язку з чим i у якій справі допитується свідок; бути присутнім під час допиту свідка; контролювати роз'яснення свідкові визначених положеннями КПК процесуальних прав; $з$ дозволу слідчого ставити свідку запитання; давати свідкові консультації; знайомитися 3 протоколом допиту і клопотати про внесення до нього змін, доповнень і зауважень, власноручно робити такі доповнення і зауваження; подавати скарги прокурору на дії слідчого; клопотати про забезпечення безпеки свідкові. Окрім того, у судовому засіданні перед проведенням допиту свідка його представник вправі клопотати про його допит 3 використанням технічних засобів 3 іншого приміщення, у тому числі за межами приміщення суду, що регламентується вимогами КПК щодо проведення дистанційного проведення окремих судових дій.

У зв'язку з вказаним, на нашу думку, для уникнення такого протиріччя та з ура- хуванням змін, внесених до Основного Закону України, доцільно п. 2 ч. 1 ст. 66 КПК України викласти у такій редакції: «користуватися під час кримінального провадження правничою допомогою представника - адвоката», а ст. 63 КПК України доповнити вказівкою на представника свідка. Стосовно захисту прав перекладача, експерта та спеціаліста дослідження не проводилися.-У той же час, як визначає правозастосовна діяльність перекладач, експерт та спеціаліст потребують такого захисту при судовому розгляді кримінальних проваджень (справ). Зокрема, не маючи юридичної освіти та відповідних знань у цій галузі, вони мають складнощі при наданні відповідей на запитання учасників сторони захисту та суду, що спонукає до збільшення строків розгляду справ по суті в судах і знижує ефективність ïx ролі у процесі доказування. У зв'язку з вищезазначеним, було б доцільним створення при експертних установах служби юридичного захисту експертів і спеціалістів. Стосовно секретарів судових засідань та судових розпорядників, то їх захист може бути потрібний, під час реалізації їх повноважень як учасників кримінального провадження, але статистичних даних та інших підстав щодо необхідності захисту таких учасників кримінального процесу не встановлено.

\section{Висновки}

За результатами дослідження чинного кримінального процесуального законодавства і правозастосовної діяльності встановлено, що повноваження захисника при наданні правничої допомоги іншим учасникам кримінального провадження має свої проблемні питання, які підлягають вирішенню, оскільки концептуальні дослідження в цьому напрямі не проводились, а ті що були здійснені - лише фрагментарно. Так, стосовно заявника, то його права 3 питання отримання правничої допомоги більш поширено повинні бути закріплені у законодавчому порядку. Відносно цивільного позивача і цивільного відповідача доцільно також розширення їх процесуальних прав під час кримінального провадження, оскільки на сьогодні вони обмежені та не відповідають їх процесуальному статусу у повному обся- 


\section{Кримінальне право, кримінальний процес та криміналістика}

зі. Незважаючи на намагання розв'язати в теоретичному і прикладному аспектах проблеми захисту свідка, деякі питання в цьому напрямі залишаються невирішеними. Законодавчі прогалини відносно процесуальних прав підозрюваного, сприяють порушенням процесуальних норм 3 боку працівників органів досудового розслідування, які допитують потенціального підозрюваного як свідка, наражаючись при цьому на порушення закону, нехтуючи правами і свободами громадян України. Процесуальні права експертів, спеціалістів і перекладачів також підлягають удосконаленню $з$ їх конкретизацією та прийняття відповідних відомчих і процесуальних актів щодо захисту їх прав. Відносно захисту прав секретарів судових засідань та судових розпорядників доцільно прийняти окремі положення в чинному КПК України, які відсутні.

\section{Лiтература}

1. Конституція України від 28.06.1996 р. Відомості Верховной Ради Украӥни. 1996.№. 30. Ст. 141 .

2. Кримінальний процесуальний кодекс України: станом на 17 серпня 2020 року. - Харків : Право, 2020. - 412 с.

3. Кримінальний процесуальний кодекс України. Науково-практичний коментар : у 2 т. T. 1 / О.М. Бандурка, E.М. Блажівський, Е.П. Бурдоль та ін.; за заг. ред.В.Я. Тація, В.П. Пшонки, А.В. Портнова. Харків. Право. 2012. 768 с.

4. Треушников М.К. Судебные доказательства: монография. Москва. Юридическое бюро «Городец» 1997. 237 с.

5. Пожар В.Г. Проблеми представництва свідка у кримінальному судочинстві. Часопис Академї адвокатури Украӥни. 2009.№ 4. Режим доступу : http://www.aau.edu.ua/ e-journal/2009-3/09pvgsks.pdf.

6. Рішення Конституційного Суду України у справі за конституційним зверненням громадянина Голованя Ігоря Володимировича щодо офіційного тлумачення положень статті 59 Конституції України (справа про право на правову допомогу) від 30 вересня 2009 р., справа № 23-рп /2009. Оббіиійний вісник України. 2009. № 79. Ст. 2694.
7. Панчук О. Окремі питання надання адвокатом правової допомоги свідку. Закон и жизнь. 2013. № 3. С. 32-34.

8. Уголовно-процессуальный кодекс Республики Молдова. Київ. 2009. 254c.

9. Уголовно-процессуальный кодекс Республики Армения от 1 июля 1998 года (по состоянию на 10.10.2020) 408c.

10. Уголовно-процессуальный кодекс Республики Казахстан по состоянию на 06.10 .2020368 c.

\section{Martovitskaya E. V. POWERS OF THE DEFENSE ATTOR- NEY IN PROVIDING LEGAL ASSISTANCE TO OTHER PARTICIPANTS OF CRIMI- NAL PROCEEDINGS}

The article provides a theoretical study of legislative, scientific and practical issues regarding the procedural grounds, mechanism and powers of the defense counsel in providing legal assistance to other participants of criminal proceedings. The procedural mechanism of involvement of the defender according to the previous and current criminal procedural legislation of Ukraine and the decision of the Constitutional Court of Ukraine was investigated. According to the results of the study, certain gaps, inconsistencies and existing shortcomings of the current criminal procedure legislation of Ukraine on the researched issues have been identified. At the same time, various scientific positions of individual scientists and scientific schools that dealt with these areas on the researched issues and materials of law enforcement practice were analyzed, as a result of which the author's own scientific views were developed and expressed.

Based on the study, specific proposals and recommendations were made to improve certain provisions of the criminal procedure legislation of Ukraine and the practice of investigators, prosecutors, investigating judges and judges. In particular, the scientific novelty of the study should include the author's contribution to the development of this issue and the scientific position on the need to improve the current CPC of Ukraine by clarifying, supplementing and amending its provisions on legal assistance at the stage of pre-trial investigation 


\section{АНОТАЦІЯ}

у статті здійснено теоретичне дослідження законодавчих, наукових і прикладних питань щодо залучення захисника у кримінальному провадженні для захисту прав інших учасників кримінального провадження. При изому проаналізовано різні наукові школи i позищї окремих науковиів відносно дослідженого напряму та матеріали правозастосовної практики, відносно яких висловлені власні наукові погляди автора. Внесено конкретні пропозииіи щодо удосконалення окремих положень кримінального процесуального законодавства України та правозастосовної діяльності з досліджених питань.

Ключові слова: досудове розслідування, кримінальний прочес, право на захист, захисник, інші учасники кримінального провадження, правнича допомога, статус, положення, закон, прочесуальні правовідносини, учасник, фуункиія, наукова позииія, слідчий, дізнавач, прокурор, слідчий суддя, права і свободи. to other participants in criminal proceedings. st.st. 63, 66 of the Criminal Procedure Code of Ukraine.

The author of the article stated that the proposals and recommendations developed in the article in the case of their legislative consolidation would help increase the effectiveness of ensuring and exercising the right to protection of all participants in criminal proceedings at different stages of the criminal process.

Keywords: pre-trial investigation, criminal proceedings, right to defense, defense counsel, other participants in criminal proceedings, legal aid, status, provisions, law, procedural legal relations, participant, function, scientific position, investigator, prosecutor, investigating judge, rights and freedoms. 